\title{
Phycoremediation of waste water from a plastic manufacturing industry with Chlorella pyrenoidosa H.Chick in laboratory study
}

\author{
Kenanga Sari, Tri Retnaningsih Soeprobowati, Riche Hariyati \\ Department of Biology, Diponegoro University \\ Jalan Prof. H. Soedarto, SH. Tembalang Semarang 50275 - Indonesia \\ e-mail: kenangasari1@gmail.com, trsoeprobowati@gmail.com.
}

\begin{abstract}
Abstrack - The plastic industries has increased by 7-8\% per year, it will cause a negative impact for the environment. The wastewater of plastic industrial contain many pollutants such as hazardous substances bensen, formaldehyde and heavy metals (Cd, Cu, Cr and $\mathrm{Pb}$ ). Heavy metals $\mathrm{Cu}$ is the most dangerous heavy metals since $\mathrm{Cu}$ can inhibit enzyme systems, remediation are needed to reduce the pollutants in the environment. One effective way is by using Chlorella pyrenoidosa H.Chick as phycoremediation agent. This study aims to assess the percentage of population growth and decline of heavy metals $\mathrm{Cu}$ after inoculation with $\mathrm{C}$. pyrenoidosa H.Chick. The method used is to cultivate C. pyrenoidosa H.Chick in plastic wastewater for 8 days and observed a decrease of percentage heavy metal Cu and population growh of C.pyrenoidosa H.Chick. Environmental factors such as temperature, salinity, pH, light intensity is maintained in order to remain stable. The data obtained with T test. After 8 days of the study turned out that C. pyrenoidosa H.Chick able to reduce Cu of $0.435 \mathrm{mg} / \mathrm{l}$ to $0.24 \mathrm{mg} / \mathrm{l}$ within 8 days and decrease percentage is $44.83 \%$, thus meeting the criteria of the quality standard of waste according to the PP. 82 of 2001 in the amount of 0.2 ppm and safe for environment.

Keywords: Chlorella pyrenoidosa, phycoremediation, water, plastic, copper.
\end{abstract}

Doi: http://dx.doi.org/10.12777/wastech.2.1.2014.13-16

Citation: Kenanga Sari, Tri Retnaningsih Soeprobowati, Riche Hariyati. 2014. Phycoremediation of waste water from a plastic manufacturing industry with Chlorella pyrenoidosa H.Chick in laboratory study. Waste Technology 2(1):8-12. Doi: http://dx.doi.org/10.12777/wastech.2.1.2014.13-16

\section{Introduction}

The use of plastics in Indonesia amounted to 20,000 tons a year from 2011, and it make plastics industry increased by $7-8 \%$ a year (Hidayat, 2011), this will cause negative impact for the environment. Plastic industrial wastewater contains hazardous materials as required in the production of plastic. additives such as bensen, carcinogenic substances and heavy metals is need to improve the physical properties of plastics. Use of heavy metals such as cadmium are used to give a bright yellow and red colors in plastic, while titanium dioxide is used as inorganic dyes to give color black, brown, red and yellow plastic. Heavy metals contained in the plastics industry is $\mathrm{Pb}, \mathrm{Cd}, \mathrm{Cu}$ and $\mathrm{Cr}$ (Soeprobowati and Hariyati, 2013).

The heavy metals in the water when disposed of will be harmful to human health and the environment as well as heavy metals can't be degraded and can accumulate into organism. One of the heavy metals that are harmful is copper $(\mathrm{Cu})$ because the concentration of heavy metals $\mathrm{Cu}$ $50 \mu \mathrm{g} / \mathrm{l}$ can inhibit the growth of green microalgae (Yang and Pan, 2002). Copper ( $\mathrm{Cu}$ ) is one of the micronutrients required by microalgae in the media. Heavy metals $\mathrm{Cu}$ involved in the process of formation energy for metabolism and in the activity of tyrosine (Palar, 2008). $\mathrm{Cu}$ exposure to large doses can cause liver damage, kidney, and even cause death (Widowati, 2006). One way to reduce the pollution on the environment is to use a method of bioremediation. Bioremediation is a way to clean up pollutant materials in environments with living organisms (Crawford and Crawford, 2005). Microalgae have the potential functions to reduce the accumulation of toxic materials and heavy metals, by accumulating, absorbing and metabolizing it at a safe level for the microalgae (Priyadarshani et al., 2011).

Phycoremediation is one of bioremediation using microalgae as an agent to reduce pollutants in the waters. There are several advantages by using microalgae as phycoremediation agent, it is easy, cheap and flexible to be applied and need little maintenance.

Chlorella pyrenoidosa H.Chick chosen as the Agent because Chlorella has many advantages, it is known that chlorella have been able to grow quickly, easily cultured, and it has small size so that it have more absorption area which make it a better absorption agent than cells that have a large size (Khoshmanesh et al., 1997) . 


\section{Experimental Methods}

The research stage is divided into three steps, they are A review of the survey area and observation of production processes and sampling sites in Plastic industries were located at Bandungrejo, Mranggen, Semarang, lab work, and data analysis. All equipments had been sterilized to eliminate or minimize the presence of microorganisms or substances. Equipment washed with dishwashing soap and then rinsed with water, then soaked in a solution of chlorine at $25 \mathrm{ppm}$ for 1 hour. The last stage is rinsed with water that has been boiled at a temperature of $100^{\circ} \mathrm{C}$ after it was sprayed with $70 \%$ alcohol.

The amount of microalgae used for culturing are $1,000,000$ cells / ml. According Rachmaniah (2010) the formula to calculate microalgae are:

Abundance (cells $/ \mathrm{ml})=\left(\frac{\mathrm{N} 1+\mathrm{N} 2}{2}\right) \times 10^{4}$

\section{Description:}

N1 = Number of microalgae boxed observations 1 .

N2 = Number of microalgae boxed observation 2 .

Density of microalgae that have been known to further incorporated into the formula:

V1. N1 = V2. N2

Description:

$\mathrm{N} 1$ = Initial inoculum cell density (cells $/ \mathrm{ml}$ ).

$\mathrm{N} 2=$ Required inoculum cell density (cells/ml).

$\mathrm{VI}=$ Volume of inoculums required $(\mathrm{ml})$.

V2 = Volume of water required media $(\mathrm{ml})$.

Observation of environmental factors include temperature, salinity, $\mathrm{pH}$, and light. Environmental factors affecting populations of microalgae. Observation of environmental factors is very important and is done every day for 8 day. After obtained results of the analysis of heavy metals, then percentage decrease in metal. According Giyatmi (2008) the percentage reduction in metals calculated by the formula:

$$
\% \text { Reduction }=\frac{\text { Cbefore }- \text { c after }}{\text { cbefore }} \times 100 \%
$$

Description :

$\mathrm{C}_{\text {before }}=$ Concentrate of Heavy metal before Micro algae cultivation (mg/l).

$\mathrm{C}_{\mathrm{after}}=$ Concentrate of Heavy metal after Micro algae cultivation (mg/l).

The data obtained is the number of density of cells, the data percent reduction of heavy metals $\mathrm{Cu}$, daily data of temperature, salinity, $\mathrm{pH}$ and light intensity data. It also calculated the Standard Deviation to see how big Error bars on the graph. Data analysis is a quantitative analysis in the form of numbers. Data processing is performed by using analysis of variance $\mathrm{T}$ test to calculate population

\section{Results and Discussion}

The growth of $C$. pyrenoidosa H.Chick for 8 days of observation is maintained in a stable condition. Environmental factors such as $\mathrm{pH}$, temperature, salinity and light affect the growth of $C$. pyrenoidosa H.Chick. The temperature is $24^{\circ} \mathrm{C}-25^{\circ} \mathrm{C}$. salinity $0 \mathrm{ppm}$, ph is 7 and light intensity is 5.395 lux.

This study used two different treatments that are cultivated $C$. pyrenoidosa H.Chick in control media (freshwater media) and C. pyrenoidosa H.Chick were cultivated in a medium of plastic wastewater. Based on observations during the 8 days $C$. pyrenoidosa cultured in freshwater media has the highest cell density compared with $C$. pyrenoidosa in plastic wastewater media.

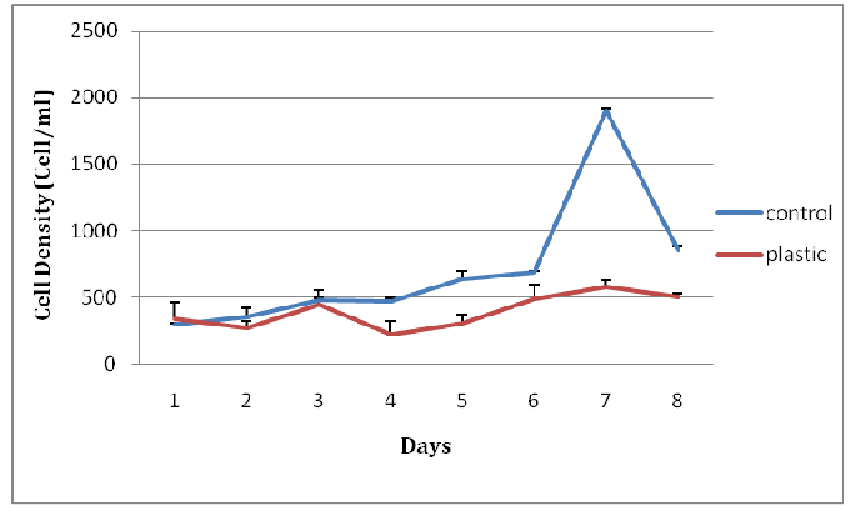

Figure 1. Growth Charts C. pyrenoidosa H.Chick

Figure 1 shows C.pyrenoidosa H.Chick which cultured on fresh water media through a phase of adaptation on day 1 and day 2 , while the $3^{\text {rd }}$ day growth phase occurs, day 4 decrease phase of cell growth occurred, days 5 increased growth phase occurred, while the 6th and 7th is the peak phase of growth, and its decreasing on the 8th day. This is consistent with Tetelepta research (2011) which states that the growth of Chlorella growth peaks on day 3 with a cell density of $8.33 \times 10^{7}$ cells / ml. $C$. pyrenoidosa cultured in freshwater media have exponential phase on day 3 and day 7. Hartanto (2013) mentions that the media controls Chlorella experiencing exponential phase on day 3 and day 6 .

C. pyrenoidosa H.Chick that are cultivated on plastic wastewater have different growth phases, day 1 to the 2nd phase of adaptation occurs, the 3rd day is the peak of the growth, the $4^{\text {th }}$ day decreasing growth occurs, the $5^{\text {th }}$ to 7 th day through a phase of growth, and day 8 the growth decreased. Based on research during the 8 days, there are significant differences on the cell density $C$. pyrenoidosa cultured in control media and media plastic wastewater. The cell density difference caused by the presence of heavy metals in the culture medium, the presence of metal components will affect physiological processes, the presence of these components affect the 
process of water absorption, respiration, mineral uptake and photosynthesis (Burzynski and Zurek, 2007).

C. pyrenoidosa H.Chick cultured on plastic industrial wastewater have delays logarithmic phase and decreased the amount of cell density. The existence of heavy metals resulting in stunted growth of microalgae, it is caused by disruption of intracellular enzyme systems, in addition to the high concentrations of heavy metals that would lead to the destruction of the cell membrane, resulting electrons and ions - ions that are important became unbalanced so that growth becomes stunted. The existence of compounds - compounds that exist in other media may also affect the growth of microalgae. According Soeprobowati and Hariyati (2013) research show that plastic wastewater medium contains heavy metals $\mathrm{Cu}, \mathrm{Pb}, \mathrm{Cd}, \mathrm{Cr}$. Presence of heavy metals such as $\mathrm{Cr}$, $\mathrm{Cd}$ and $\mathrm{Pb}$ are not needed by microalgae for respiration or for growth, but there is increasing industry will increase the amount of $\mathrm{Cr}, \mathrm{Cd}$ and $\mathrm{Pb}$ in the waters. $\mathrm{Cd}$ is one of the most stable metals in waters, while $\mathrm{Pb}$ was the metal most easily accumulated into microalgae. presence of heavy metals in microalgae will negatively affect for cell division, cell growth and also interfere with the enzymatic process, the presence of heavy metals can also result in $50 \%$ mortality microalgae. The existence of $\mathrm{Cr}$ in a medium will degrade biomass and chlorophyll content of microalgae as $\mathrm{Cr}$ interfere in the process of photosynthesis. The existence of $\mathrm{Pb}$ and $\mathrm{Cd}$ in the media will lead to a growth of microalgae be hampered because both of these metals induce peroxide enzyme activity which plays an important role in the degradation Indol acid acetate (IAA). IAA hormone is a hormone that stimulates the growth and division of microalgae (Lamai et al., 2005). The measurement results show that plastic waste water media has a heavy metal content of $\mathrm{Cu}$ was $0.435 \mathrm{mg} / \mathrm{l}$

Table 1. Concentration of $\mathrm{Cu}$

\begin{tabular}{cccc}
\hline Day & $\begin{array}{c}\text { Concentration of } \\
\text { Cu in the plastic } \\
\text { wastewater } \\
(\mathrm{mg} / \mathrm{l})\end{array}$ & $\begin{array}{c}\text { Percentage } \\
\text { decrease }\end{array}$ & $\begin{array}{c}\text { Criteria for } \\
\text { waste quality } \\
\text { standards }\end{array}$ \\
\hline H0 & 0.435 & $44.83 \%$ & $44.83 \%$ \\
H7 & 0.24 & & \\
\hline
\end{tabular}

Table 1 shows $C$. pyrenoidosa cultivated by the media plastic wastewater can reduce the content of heavy metals $\mathrm{Cu}$. $\mathrm{T}$ test analysis results showed that the freshwater media and plastic media wastewater significantly different ( $\mathrm{P}>0.05$ ) against $C$. pyrenoidosa H.Chick population growth. Based on the results of the $\mathrm{T}$ test statistic can be concluded that $t(1,803)>t$ table (1.782), so there is a difference between the growth in freshwater medium with plastic wastewater. Percentage decrease in $\mathrm{Cu}$ levels are at $44.83 \%$ and the final concentration of $\mathrm{Cu}$ concentration is $0.24 \mathrm{mg} / \mathrm{l}$. Criteria for waste quality standards according to the PP. 82 of 2001 regarding the quality of raw water source of copper for fourth grade is used for industry is $0.2 \mathrm{mg} / \mathrm{l}$. $C$. pyrenoidosa have the ability to absorb heavy metals. Research conducted for 8 days can decrease copper toxicity by $44.83 \%$ when the study was conducted in a longer period of time is expected to decrease the toxicity of copper up to $90 \%$.

Based on these studies the cultivation of $C$. pyrenoidosa $\mathrm{H}$.Chick time should be extended for 14 days to increase the percentage of absorption of heavy metals. This was confirmed by research conducted by Brady (1994) which revealed that Scenedesmus, Selenastrum and Chlorella able to remediate metals such as copper, lead, and chromium with 67-98\% efficiency.

\section{Conclusion}

After doing research for 8 days, C. pyrenoidosa could grow in the wastewater of plastic industry but the growth of microalgae is lower compared with controls. The percentage reduction of heavy metal $\mathrm{Cu}$ is equal to $44.83 \%$ during the 8 days of observation. C. pyrenoidosa H.Chick able to effectively remediate heavy metals. The initial concentration before cultivation was $0.435 \mathrm{mg} / \mathrm{l}$ and after being treated with C. pyrenoidosa H.Chick the final concentration become $0.24 \mathrm{mg} / \mathrm{l}$.

\section{References}

Brady, D. and Duncan, J. R .1994. Bioaccumulation of metal cations by Saccharomyces cerevisiae. Appl. Microbiol. Biotechnology. 41: 149 - 154.

Burzynski, M., Zurek, A. 2007. Effects of copper and cdmium on photosynthesis in cucumber cotyledon.Photosyntetica 45,239-244.

Crawford R.L., and Crawford D.L., 2005, Bioremediation: principles and applications, Cambridge University Press, New York, pp. 406.

Giyatmi, K., Zaenul, M., .Damajati. 2008. Penurunan Kadar Cu,Cr dan Ag Dalam Limbah Cair Industri Perak di Kotagede detelah Diadsorpsi dengan Tanah Liat dari Daerah Godean. Jurnal Seminar Nasional IV SDM Teknologi Nuklir ISSN 1978-0176

Hartanto, H. S. 2013. Pertumbuhan Populasi Chlorella vulgaris Beijerinck dengan PerlakuanPenambahan Logam Berat Tembaga $(\mathrm{Cu})$ Pada Skala Laboratorium. Skripsi. Jur. Biologi Fakultas Sains dan Matematika Univ. Diponegoro, Semarang.

Hidayat, 2010. Industri Plastik di Indonesia.Jakarta :Sinar Harapan. Mei 22.

Khoshmanesh, A., Lawson, F., Prince, I.G., 1997. Cell surfacearea as a major parameter in the uptake of cadmium by unicellular green microalgae. Chem. Eng. J. 1, 13-19.

Lamai, C., Kruatrachue M., Pokethitiyook P., Upatham E.S., and V. Soonthornsarathool., 2005, Toxicity and Accumulation of Lead and Cadmium in the Filamentous Green Alga Cladophora fracta (O.F. Muller ex Vahl) Kutzing: A Laboratory Study. Science Asia 31: 121-127.

Palar, H. 2008. Pencemaran dan Toksikologi Logam Berat. Jakarta: penerbit Rineka Cipta

Peraturan Pemerintah Nomor 82 Tahun 2001 Tentang Pengelolaan Kualitas Air Dan Pengendalian Pencemaran Air.

Priyadarshani I., Sahu D., and Rath B., 2011, Microalgae bioremediation: current practices and perspectives. Journal of Biochemistry Technology 3(3): 299-304

Rachmaniah. 2010. Pemilihan Metode Ekstraksi Minyak Alga dari Chlorella pyrenoidosa dan Prediksinya Sebagai Biodiesel, dipresentasikan pada Seminar Teknik Kimia Soehadi Reksowardojo, ITS Surabaya

Soeprobowati, T.R., and Riche ,H. 2013. Potensi Mikroalga sebagai Agen bioremediasi dan aplikasinya dalam 
penurunan konsentrasi logam berat pada instalasi pengolah Air Limbah Industri. Laporan Penelitian. Penelitian Fundamental. Lembaga Penelitian dan Pengabdian Kepada Masyarakat. UNDIP.Semarang

Tetelepta, L.D. 2011. Pertumbuhan Chlorella Sp Skala Laboratorium Pada Beberapa Tingkat Kepadatan Inokulum. ISBN: 978-602-98439-2-7
Widowati, W. 2006. Efek Toksik Logam. Yogyakarta: Penerbit ANDI.Halaman 184, 185,202, 203.

Yang, H., and G. Pan. 2002. Toxicology and Bioaccumulation Copper in Three Green Microalgal Species. Chemosphere 49:471-476. 